\title{
THE FEATURES OF PRE-SCHOOL AND PRIMARY SCHOOL CHILDREN'S VALUE FORMATION PROCESS AND THE DEVELOPMENT OF THEIR WORLDVIEWS
}

\author{
Tamara Pirozhenkol, Olena Khartman ${ }^{2}$, Iryna Soroka ${ }^{3}$ \\ ${ }^{1}$ Corresponding Member of the National Academy of Educational Sciences of Ukraine, Professor, DSc. in \\ Psychological Sciences, Head of the Laboratory of Preschool Psychology, G.S. Kostiuk Institute of Psychology, the National \\ Academy of Educational Sciences of Ukraine, Kyiv (Ukraine) \\ ORCID ID: http://orcid.org/0000-0001-9822-4819 \\ ${ }^{2}$ PhD. in Psychological Sciences, Senior Researcher, Laboratory of Preschool Psychology, G.S. Kostiuk Institute of \\ Psychology, the National Academy of Educational Sciences of Ukraine, Kyiv (Ukraine) \\ ORCID ID: http://orcid.org/0000-0002-3380-4836 \\ Sonipat (India) \\ ${ }^{3}$ PhD in Psychology, Associate professor, O.P. Jindal Global University, Jindal Institute of Behavioural Sciences, \\ ORCID ID: http://orcid.org/0000-0003-1132-488X
}

UDC: 159.9 .07

\begin{abstract}
Value orientations are reflected in a child's worldview. Scientists have a common opinion that a person's worldview begins to be formed in childhood. The key purpose of the study was to analyze the data received from a survey of senior pre-school and primary-school age children with the help of an interview "Factors of a child's choice of socially significant values", describe the features of a value formation process and measure the levels of pre-school and primary-school children's worldviews. The structural and dynamic qualitative characteristics of "value orientations" system were represented by the unity of its components: 1) cognitive; 2) emotional; 3 ) behavioral. The sample consisted of children from various regions of Ukraine. The following levels were distinguished in our research based on the manifested qualitative characteristics of worldviews: a formed picture of the world (the high level); expressed worldviews (the above average one); existing worldviews (the average level); limited worldviews (the below average one); fragmentary worldviews (the low level). The data showed that the majority of Ukrainian preschool and primary-school children had the high and above-average levels of worldview formation. We analyzed emotional, cognitive, and behavioral manifestations of children's worldviews and generalized characteristics typical for children groups formed based on the levels of worldview formation.
\end{abstract}

Keywords: value orientations, worldviews, spirituality, cognitive, emotional, behavioral components.

\section{Introduction}

One of the basic principles of pre-school education is to familiarize children with social-cultural norms, traditions, and values of the family, society and the state. According to worldwide estimations, up to $50 \%$ of children attend pre-school (UNICEF, 2019) and pre-school attendance is associated with better school readiness and academic achievement (Barnett et al., 2010).
Moral education is one of the main tasks of almost all pre-school educational programs. As a result, choosing and rational use of various methods forming children's moral values is currently an important problem of preschool education. Over time, children master the norms and rules of behavior and relationships accepted in the society, assimilate the ways and forms of interaction, expressions of attitude to people, the nature, oneself. The result of moral

Address for correspondence, e-mail: editpsychas@gmail.com

Copyright: (C) Tamara Pirozhenko, Olena Khartman, Iryna Soroka

This is an Open Access journal, all articles are distributed under the terms of the Creative Commons Attribution-NonCommercial-ShareAlike 4.0 International (CC BY-NC-SA 4.0) License (http://creativecommons.org/licenses/by-nc-sa/4.0/), allowing third parties to copy and redistribute the material in any medium or format and to remix, transform, and build upon the material, provided the original work is properly cited and states its license. 
education is an emerged and affirmed set of moral qualities.

And the stronger these qualities are, the fewer deviations from the moral foundations accepted in society are observed, the higher is the individual's morality as it is assessed by others (Pirozhenko et al., 2020).

The analytical review of research materials on personality development has revealed that one of the leading trends in the educational situation today is the transition to a value paradigm, which provides an increased attention to the formation of a child's value semantic sphere. The issues of worldview formation in children of different ages remain opent in the modern world. The analyzed scientific literature helped us to identify the most significant factors influencing the development of children's worldview: a healthy atmosphere in the family, close communications with parents and relatives, efficiently organized children's daily routine with sufficient conditions for their games, rest, nutrition, development of aesthetic taste, speech, visiting exhibitions and theatrical performances (Pirozhenko, 2017), learning opportunities and environments (Ray, 2010).

A child's personality is formed and developed during education, socialization and self-development. It is known that the basis of spiritual and moral development is the culture of the society, family and educational institutions - the environment in which the child lives, their personality is formed and developed. Culture is, first of all, a system of values enshrined in traditions. Assimilation of culture is necessary for the satisfaction of spiritual needs and the searches for higher values.

Pre-school age is a special time in personality formation, when the foundations of spiritual and moral values are laid down. During this period, an emotional attitude to spiritual and moral values is firstly formed in children. The features of preschoolers' worldview formation were considered in developmental psychology by Vygotsky (1991), Leontiev (1992). The value formation in pre-school children and their spirituality are the issues that are widely researched as well.

According to Pirozhenko et al. (2016) a major obstacle to understanding the essence of spirituality is attempts to connect it only with certain areas, aspects of human life, such as religious faith, attitudes toward works of art, literature, moral issues or human relationships. To overcome this obstacle we should understand that spirituality is of the universal nature and manifested in human activities and behavior at all. So, everything that a person does, the way he/she behaves, needs and values that motivate his/her activities can be evaluated from the standpoint of spirituality.

Considering the universal, all-encompassing nature of spirituality, we can say that this feature is inevitably manifested in personal characteristics. The theoretical analysis of the essence of spirituality (Pirozhenko et al., 2016; 2017; 2020, Ukhtomsky,1996) shows that value orientations are directly or indirectly connected with a person's attitude to him/herself and other people, with morality and ethics.

Values are manifested in three forms: 1) as a social ideal, as an abstract idea existing in various spheres of social life and developed by public consciousness; such values can be universal, "eternal" (the truth, beauty, justice); 2) as artifacts of material and spiritual culture or human activities - specific object-based incarnations of social value ideals (ethical, political, legal, etc.); 3) as social values, refracted through the prism of an individual life and included into the psychological structure of a personality as personal values - a source of behavioral motivation. Values can be material and spiritual; all-human and national; family, professional or corporate.

In the pre-school age, emotions and feelings are of particular importance for acceptance of moral values. Moral values are a reflection of people's real relations and their attitudes to various forms of the society's life; they are formed on a set of principles, rules, norms, assessments that regulate people's communication and behavior to achieve the unity of public and personal interests.

We should emphasize that value orientations occupy a special place in an individual's spirituality together with aspirations, hopes, perception of the world, awareness of a life meaning and purpose, and understanding of behavioral motives. The universal nature of value orientations as life regulators was taken into account in our research, where a meaningful holistic picture of children's world, worldviews and values was analyzed in various activity areas, such as "Human and Nature", "Human and Society", "Human and Culture", "Human and the Universe", "Human, Science and Technology" through the characteristics of children's outlook, cognitive interests, depth of their 
DOI (Issue): https://doi.org/10.31108/1.2021.7.5

knowledge, choices made by them (Pirozhenko et al., 2017).

\section{Literature review}

The theoretical and methodological analysis of the formation of pre-school age children's value orientations and their worldviews includes several related complementary concepts: worldview - picture of the world - attitude to reality (Pirozhenko et al., 2020).

The pre-school and primary-school age has deep potential opportunities for worldview spiritual development. If parents provide spiritual and moral support to develop their child's value sphere, values are accepted harmoniously at older ages, the vision of the world becomes positive and adequate, and behavior is prosocial (Katrenka, 2017 , p. 56).

The formation of primary school children's spiritual and moral values should be monitored and timely corrective work, psychological educationand counseling of parents and teachers should be carried out. Value orientations are reflected in a child's worldview. Scientists agree in general that a person's worldview begins to be formed is childhood - in the early, pre-school period of gaining life experience.

The modern scientific literature understands "a child's worldview" as the child's inner view on the world in its integrity, diversity, relationships, and interdependencies; awareness of the importance of the world in life; the ability to see the main thing in it, to feel, to look around, to discover, to enrich one's life ideas, impressions, experience; the ability to understand the meaning and value of the world, the importance of oneself for the people around, the ability to solve problems constructively. Karpenchuk (2005) argues that a worldview is a generalized system of views, beliefs and ideals helping a person expresses his/her attitudes to the natural and social environment. The formation of a child's worldview involves a holistic view of the world created in his/her mind, understanding of a person's place in the world, self-esteem. The system of a senior preschooler's current value orientations indicates the extent to which the child's activities and experience can be used for new developmental tasks to master new activities, to establish new social contacts with adults and peers.

The formation of a preschool child's value orienta-
Volume 7 Issue 5 (49) 2021

tions is an answer to the question of how the social world becomes accessible to analysis, understanding, and assimilation by the child. The generalized conclusion confirms that a value choice is made through the course of emotional states (interest, surprise, admiration) and more complex emotional feelings (ethical, aesthetic, intellectual) and based on mind, and this choice is realized through activities that, accordingly, require development of volitional regulation.

The characteristics of the system of senior preschoolers' values existing in real life can be described in two areas: the scope and content of a value system existing in children's subculture ("a child's values") and psychological features of the formation of a pre-school child's values ("structural and dynamic characteristics of value orientations").

The structural and dynamic qualitative characteristics of value orientations create the unity of the following components: 1) the cognitive component that characterizes the content, saturation of a child's value system and consists of evaluative judgments, knowledge of reality and him/herself; 2) the emotional component that characterizes the subjective, personal attitude to an evaluated object in the surrounding natural and social reality; 3) the behavioral component that characterizes the inclusion, penetration of evaluative judgments into a child's real life and formed volitional, regulatory behavioral mechanisms used by the child in various specifically children's activities. It is now recognized that children's healthy development includes not only their cognitive abilities but also children's physical, mental, social, and emotional well-being (Hair et al., 2006). Davies et al. (2016) studied such factors as motivation, self-regulation and physical capacities that influence children's further success in school. In the study made by Piotrowska et al. (2020) kindergarten data was compared with educational, health and protection records.

Modern researchers emphasize that environmental ideas should be formed in children from an early to preschool age and they should be taught about human and the nature and how they interact with each other and fit together (Davranova, 2021). It is essential to equip children from an early age with ecological knowledge of nature conservation and familiarize them with the nature, enriching their perception, developing their worldview, independent think- 
ing skills and spiritual feelings. At the present stage of society, environmental awareness, as well as environmental worldview are crucially important and the ecological education of pre-school children must be organized (Demidov et al.,2019).

Modern researchers also discussed worldview formation and religious worldview in association with children's cognitive development, social learning, and socialization (Helve, 2015). Appleton (2020) suggested that children and adolescents need spiritual nurturing and teaching to instill a biblical worldview and to make possible the lifelong spiritual development.

Zdanevych et al. (2020) emphasized the unification of methods used for moral and ethical education of children to develop an educational model that would contribute to children's optimal understanding of basic moral principles.

Therefore, the study purpose was to identify the features of pre-school and primary-school children's value formation process and estimate their worldviews.

The following research questions were proposed to achieve the article aim: (1) What are the psychological features of the value formation process in pre-school and primary-school children? (2) Which levels of worldview development have pre-school and primary school children? These research questions were the guide for our study.

\section{Methodology}

To identify psychological and pedagogical factors influencing acceptance of values by senior pre-school and primary-school age children and their specifics, we used the following methods: theoretical analysis, interactive educational methods, questionnaires, interviews, observations and mathematical methods for statistical analysis of obtained data: the determination of averages for existing (assimilated by children) values for all series of observations; division by levels for examined features; calculation of relative and absolute deviations, comparative analysis of the obtained data. Calculations were performed in MS Office Excel.

\section{Research design}

To resolve theoretical and experimental issues, a set of examining tools was used that helped to analyze the system of existing real-life values in two directions - the scope and content of the value system existing in children's subculture, which was named "Field of values", and psychological features of the value formation process in preschool children, which was named "Structural and dynamic characteristics of value orientations" (Pirozhenko et al., $2016 ; 2017)$. The used methods took into account the specific formation of pre-school children's value orientations, namely, they included the criteria to characterize them and to estimate their manifestations by children. "Express examination of preschoolers' value orientations" method, observation maps: "Indicators of development of the activity component of value orientations", "Indicators of preschoolers' values manifested in real and game relations" allowed us: 1) to determine what values and to what degree are manifested in different situations; 2) to determine the structural characteristics and the effectiveness of values in children's real life.

Children were offered values from different areas of human relations with the world: "human - human", "human - the nature", "human - technology", "human - the art" to make a choice and explain their choice, and children is asked to determine their attitude to the following values:

terminal: family, happiness, health, friendship, beauty of the nature, of the art and of the technology, external beauty, creativity, money;

instrumental: empathy, independence, curiosity, purposefulness, confidence, courage, persistence.

An interview "Factors of a child's choice of socially significant values" was designed to survey senior preschool and primary-school age children. The first block of this interview comprises the question for "Acquaintance. General information". The following questions specify a child's worldview concerning the cultural and aesthetic sphere and situations of uncertainty (worldviews in action): "Have you ever been to a theatre, an exhibition or a game center? How often do you go there? Tell me about it."; "What are the rules of conduct that must be followed when in public? Do you think it is always necessary to follow them?"; "In a place where there are a lot of people, it is possible to get lost, if so, what will you do? Who will you turn to for help?"

A child's choice of values was analyzed by the following indicators: modality - emotional and value attitude towards themselves, others, and the world around them; general ideas about values existing in the world - 
knowledge, ideas about the phenomena of the surrounding reality; behavioral manifestations - a child's specific actions in everyday life, what draws the child's attention, what he/her considers, what he/her is guided by, how he/ she explains his/her actions.

The children's recorded responses were processed quantitatively and scores were obtained. The data obtained in the conversation with children were supplemented by observational materials and joint interactions with them in various activities and was evaluated according to the criteria presented in the above mentioned methods.

Basing on the used psychometric methods and mathematical statistics, we determined how 6-7 year old children rated different socially significant values. This ranking of values (rating) allowed us to assess choices made by each child and corresponding significance of rated values.

\section{Sample}

The sample consisted of children from various regions of Ukraine. Educational institutions - partners of the Laboratory of Preschool Psychology, Ukraine participated in sampling and examination. The laboratory had agreements on specific scientific topics with the partners.

The total number of participants was 306 children (166 girls, 140 boys): 190 senior preschoolers age of 6 years old (44 were brought up at home only, 146 attended pre-school educational institutions); 116 primary schoolchildren of 7 years old (all of them studied in primary school/the 1 st form of general schools), Table 1.

\section{Research Tools and Procedure}

The standardized "Express examination of preschoolers' value orientations" method was used in this research (Pirozhenko et al., 2014, p.30-32), it was based on the methods studying human values (Rokich,1992; Peterson \& Seligman, 2004)

The survey procedure: socially significant values chosen by examined children were recorded at two stages. During the first stage, the children chose eight important values from the list of terminal and instrumental values. The experimenter recorded the selected values. During the second stage, the children chose the four most important values for them from already selected ones. The experimenter also recorded the order of choices (ranking).

Materials: 17 plot pictures in black-and-white graphic, depicting characteristics of value orientations: family, happiness, health, friendship, empathy, the beauty of the nature, of the art and techniques, external beauty of a person, independence, curiosity, creativity, determination, confidence, courage, perseverance, money.

Instructions for children: Here are the pictures. The artist illustrated the things important in life. Carefully consider them and choose a picture about:

1. Family. Then, a child is asked to explain this concept: "What does this word mean? Please, explain how you understand it", etc. The results are recorded in the form. Interpretation:

"0" points - a child cannot choose a picture corresponding to the mentioned concept, cannot explain the con-

Table 1. Demographic characteristics of the participants $(n=306)$

\begin{tabular}{|c|c|c|c|}
\hline \multirow{2}{*}{ No } & \multirow{2}{*}{ Demographic Characteristics } & \multicolumn{2}{|c|}{ Children } \\
\hline & & Total & $\%$ \\
\hline \multirow{3}{*}{1.} & Gender & & \\
\hline & Male & 140 & 45.75 \\
\hline & Female & 166 & 54.25 \\
\hline \multirow{3}{*}{2.} & Age & & \\
\hline & 6 & 190 & 62.09 \\
\hline & 7 & 116 & 37.91 \\
\hline \multirow{4}{*}{3.} & Education & & \\
\hline & Home & 44 & 14.38 \\
\hline & Pre-school institution & 146 & 47.71 \\
\hline & Primary school & 116 & 37.91 \\
\hline
\end{tabular}


DOI (Issue): https://doi.org/10.31108/1.2021.7.5

cept;

"1" point - a child chooses a picture (provided by the experimenter, or makes another choice) and explains the concept according to the situation depicted in the picture;

"2" points - a child chooses a picture (provided by the experimenter, or makes another choice) and gives a generalized explanation of the concept.

The theoretical analysis and experimental study of worldviews as a factor influencing children's acceptance of value orientations allowed us to make the following conclusions: happiness, family, friendship, and the beauty of the nature were the most important socially significant values for both preschoolers and first-form schoolchildren.

Preschoolers were capable to determine consciously socially significant values and could differentiate "good" from "bad" and consciously choose "good", explaining the choice. For example: "It is impossible to be happy without a family" or "Happiness is when you have a mother, a father, a brother and a sister".

Socially significant values accepted by children on the cognitive (they could explain what it was; had corresponding ideas), emotional (they knew that was right) and behavioral (values guided them in everyday life) levels. Through the picture of a child's world, we can "see" the formation of the child's attitudes to life, to him/herself (self -esteem, level of aspiration), to other people, which was manifested in values. Worldviews were related to all mental achievements of senior preschoolers; at the same time, worldviews were the basis and result of gained life experience and acted as an indicator of a child's psychological maturity.

\section{Validity and Reliability}

"Express examination of preschoolers' value orientations" (Pirozhenko et al., 2014, p.30-32) is a standardized test and its validity and reliability was proved in previous studies.

\section{Results}

The study showed that the majority of children attending pre-school educational institutions (87.64\%) and primary school $(89.07 \%)$ had sufficiently formed ethical views in child-adult interactions, which indicated that they assimilated ethical norms of social relations, had ideas about themselves as an object and a subject of social rela-
Volume 7 Issue 5 (49) 2021

tions.

In our study, we distinguished the following qualitative levels based on worldview characteristics: a formed picture of the world (the high level - 5 points); expressed worldviews (the above average level - 4 points); existing worldviews (the average level - 3 points); limited worldviews (the below average level - 2 points); fragmentary worldviews (the low level - 1 point).

The performed quantitative analysis of empirical data revealed what values were accepted at the behavior level by children aged 6 to 7 years, depending on their formed worldviews and ranks of acceptance of socially significant values. For children with the formed picture of the world, the values of "family", "happiness", "health" were significant (accepted), they are presented here in the order of lowering their rank (from higher to lower). For children with expressed worldviews, such values were "health", "beauty of the nature", "family". For children with the average level of worldviews formation, the values of "money", "health", "family" were significant.

6-7 year old children attending pre-school and primary education institutions had the following distribution by the formation level: the high level of worldview formation had $52.94 \%$ of the respondents (162 children); the above average level did $20.91 \%$ (64 children); the average one had $17.65 \%$ (54 children) and the below average level had $8.5 \%$ (26 children). No one from the total sample (306) showed the low level.

The analysis of emotional, cognitive and behavioral manifestations of the worldview allowed us to generalize the characteristics typical for children groups depending on the level of their picture of the world, see Table 2 .

Children with fragmentary worldviews (the low formation level) have certain ideals, which are mostly related to material rather than moral or spiritual values; they are rude, almost always negative; they have pragmatic desires without even an elementary system of value orientations; they are often worried or anxious; it is difficult for them to express their views, even with the help of an adult; they do not have clear life plans, goals, do not act according their aspirations. Such children behave inappropriately in unfamiliar or complicated situations and do not focus on possi- 
Table 2. Worldview formation in children of senior pre-school and primary school age

\begin{tabular}{|c|c|c|c|c|}
\hline Level & $\begin{array}{l}\text { Respondents (in \% } \\
\text { and } \\
\text { number) }\end{array}$ & Cognitive component & Emotional component & Behavioral component \\
\hline High & $\begin{array}{l}52.94 \% \\
(162 \text { children })\end{array}$ & $\begin{array}{l}\text { the holistic view of } \\
\text { the world; a child knows that every- } \\
\text { thing in the world is interconnected, } \\
\text { knows about the } \\
\text { fluidity of life (the past, the present, } \\
\text { the future), has life plans, goals, acts } \\
\text { according to } \\
\text { his/her aspirations }\end{array}$ & $\begin{array}{l}\text { a child is emotionally receptive, } \\
\text { has positive attitudes and a } \\
\text { formed system of value orienta- } \\
\text { tions, is optimistic }\end{array}$ & $\begin{array}{l}\text { a child tries to defend his/her position } \\
\text { calmly and tolerantly, behaves adequately } \\
\text { and flexibly in unfamiliar or complicated } \\
\text { situations, focuses on possible conse- } \\
\text { quences if he/she makes decisions }\end{array}$ \\
\hline \begin{tabular}{|l} 
Above \\
average
\end{tabular} & $\begin{array}{l}20.91 \% \\
(64 \text { children })\end{array}$ & $\begin{array}{l}\text { a child knows that everything in the } \\
\text { world is interconnected, } \\
\text { knows about the } \\
\text { fluidity of life (the past, the present, } \\
\text { the future), has vague life plans, } \\
\text { goals, does not act according to } \\
\text { his/her aspirations }\end{array}$ & $\begin{array}{l}\text { a child has a positive attitude to } \\
\text { self and his/her inner world, is } \\
\text { emotionally receptive, has al- } \\
\text { most always positive mood, is } \\
\text { optimistic }\end{array}$ & $\begin{array}{l}\text { a child tries to defend his/her position by } \\
\text { dominating, behaves adequately in diffi- } \\
\text { cult situations, focuses on possible conse- } \\
\text { quences if he/she makes decisions }\end{array}$ \\
\hline Average & $\begin{array}{l}17.65 \% \\
\text { (54 children) }\end{array}$ & $\begin{array}{l}\text { a child knows that the world consists } \\
\text { of the nature, objects, people, about } \\
\text { the fluidity of life, has vague life } \\
\text { plans, goals, does not act according to } \\
\text { his/her aspirations }\end{array}$ & $\begin{array}{l}\text { in most cases, a child is emo- } \\
\text { tionally receptive, has almost } \\
\text { always positive mood, some- } \\
\text { times anxious }\end{array}$ & $\begin{array}{l}\text { a child tries to defend his/her position by } \\
\text { dominating, sometimes by force, ade- } \\
\text { quately behaves in difficult situations, } \\
\text { focuses on possible consequences if he/ } \\
\text { she makes decisions }\end{array}$ \\
\hline $\begin{array}{l}\text { Below } \\
\text { average }\end{array}$ & $\begin{array}{l}8.5 \% \\
(26 \text { children })\end{array}$ & $\begin{array}{l}\text { a child knows about the fluidity of } \\
\text { life (the past, the present, the future), } \\
\text { can express his/her views only with } \\
\text { the help of an adult, has no clear life } \\
\text { plans or goals, does not act according } \\
\text { to his/her aspirations }\end{array}$ & $\begin{array}{l}\text { a child is emotionally unrespon- } \\
\text { sive, has almost always nega- } \\
\text { tive mood, sometimes anxious }\end{array}$ & $\begin{array}{l}\text { a child tries to defend his position by } \\
\text { dominance and force, cannot always dif- } \\
\text { ferentiate good and evil, does not focus on } \\
\text { possible consequences if he/she makes } \\
\text { decisions }\end{array}$ \\
\hline
\end{tabular}

ble consequences (approval, resistance, punishment, etc.) if they makes decisions.

Among senior preschoolers (190 children), 57.89\% (110 children) had the high level of worldviews formation; $13.68 \%$ (26 children) had the above average level; $20.0 \%$ (38 children) had the average level; and 8.42\% (16 children) had the below-average level.

As for the primary school children (116 children), the results were distributed as follows: $43.10 \%$ (50 children) had the high level of worldviews formation; $32.76 \%$ (38 children) had the above-average level; $15.52 \%$ (18 children) had the average level; and $8.62 \%$ (10 children) had the below-average level (see Figure 1).
We grouped the examined values based on the children's choice of values. Subgroup I included values chosen the most often, subgroup II included values chosen less often, and subgroup III included values chosen rarely. For senior preschoolers attending pre-school educational institutions, the socially significant values (important for children) were distributed as follows: subgroup I included happiness, family, the beauty of the art; subgroup II included independence, the beauty of the nature, money; subgroup III included health, empathy, determination. For primary schoolchildren, the socially significant values were distributed as follows: subgroup I included health, family, the beauty of the nature; subgroup II included creativity,

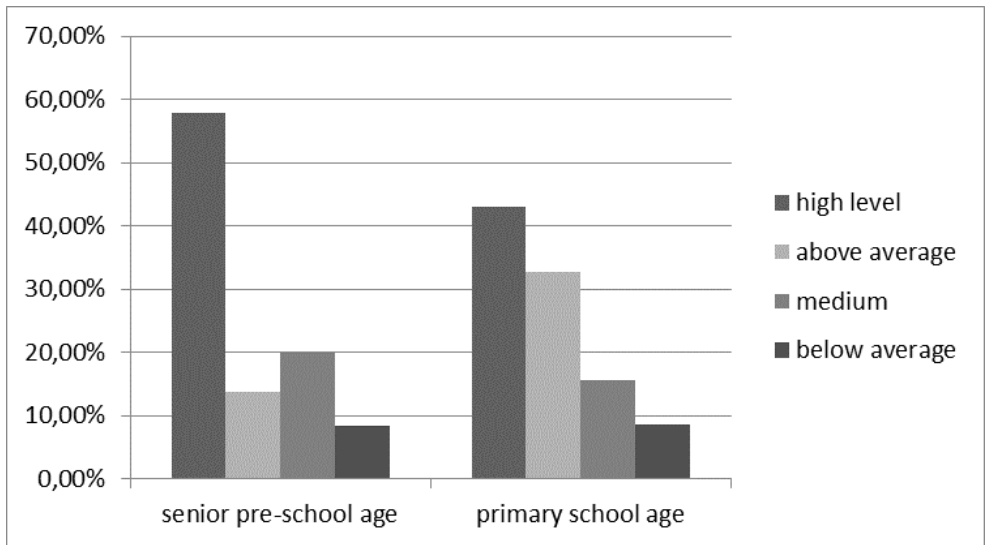

Figure 1. Comparison of worldview formation between senior preschoolers and primary schoolchildren 
money, courage; subgroup III included independence, friendship, perseverance. See Table 3. schoolchildren, we should note that they chose mostly average-rated values. Significant difference in choice assess-

Table 3. Distribution of socially significant values for pre-school and primary school children

\begin{tabular}{|c|c|}
\hline Subgroup & Values (pre-school children) \\
\hline $\mathbf{I}$ & $\begin{array}{l}\text { happiness, family, the beauty of the } \\
\text { art }\end{array}$ \\
\hline II & $\begin{array}{l}\text { independence, the beauty of the na- } \\
\text { ture, money }\end{array}$ \\
\hline III & health, empathy, determination \\
\hline
\end{tabular}

The following differences were found for socially significant values chosen by senior preschoolers and primary schoolchildren: among senior preschoolers, 34.74\% (66 children) scored 3 points (they chosen the highest rating values); 43.16\% (82 children) score of 2 points; and 22.11\% (42 children) scored 1 point. Among primary schoolchildren, 18.97\% (22 children) scored 3 points (they chosen the highest rating values); $56.9 \%$ (66 children) scored 2 points; $24.14 \%$ ( 28 children) scored 1 point.

The largest difference was obtained for the assessment of high-rated socially significant values, if we say in the terms of scores received by senior preschoolers and primary schoolchildren during value choosing. This difference achieved $15.77 \%$ in favor of senior preschoolers. As for averagely rated values, the difference was $13.74 \%$ in favor of primary schoolchildren. The percentage of the respondents in both groups chosen low-rated values was quite close. The difference was only $2.03 \%$ in favor of primary schoolchildren.

As for characteristics of children's choice of socially significant values depending on worldview formation, a direct relation was found between the levels of senior preschoolers' worldviews formation and their assessments of socially significant values. Children with the high or above average levels of worldviews formation chose values with high and average rating indexes. Children with the low or below average levels of worldview formation chose values with low and average rating indexes. Only $7.27 \%$ of 55 children with the high level of worldview formation chose low-rated values, but $45.45 \%$ chose highrated values. 8 children had the below average level of worldviews formation, $50.00 \%$ of them chose low-rated values, and only $12.50 \%$ chose high-rated values. If compare the data obtained within the age groups of primary

Values (primary school children)
health, family, the beauty of the nature
creativity, money, courage
independence, friendship, perseverance

ment was revealed only for two opposite groups: children with formed worldviews and children with limited worldviews ( $28 \%$ and $60 \%$ of them chose low-rated values, respectively).

\section{Discussion}

The influence of the social situation (pre-school educational institution/school) on development can be considered as an external factor influencing acceptance by children of socially significant values.

Basing on the survey results, we can say the following: for six-seven year old children attending different educational institutions (pre-school and primary school), terminal and instrumental values were distributed proportionally: 6 out of 9 terminal; 3 out of 9 instrumental.

The values significant for senior preschoolers and first-form schoolchildren coincided by $50 \%$ (5 out of 9 ). Even if values were different, they coincided in type (terminal or instrumental). This gives us the reason to state that "field of values" remains unchanged qualitatively during transition from pre-school and primary education.

Children's ability to choose and accept socially significant values depends on their cognitive development and is manifested through the content, saturation of evaluative judgments, knowledge of the surrounding reality and themselves, i.e. concepts composing children's system of values.

The difference between the high and above average levels of children's worldview formation was quite visible. This may be children's reaction to the adaptation period at school, when the leading type of activities is changed, intellectual load is increased, lesson system appears, as well as new children's teams.

As for characteristics of children's choice of socially significant values depending on worldview for- 
mation, a direct relation was found between the levels of senior preschoolers' worldviews formation and their assessments of socially significant values. Children with the high or above average levels of worldviews formation chose values with high and average rating indexes. Children with the low or below average levels of worldview formation chose values with low and average rating indexes. The analysis of the values that children choose depending on their levels of worldview formation confirmed the already outlined trend. Senior preschoolers attending educational institutions, as well as first-form schoolchildren with the high level chose higher-ranked values, while children with fragmentary worldviews chose low-ranked values. The quantitative analysis of obtained empirical data correlates with the normal data distribution law, which gives us reason to consider preschoolers' worldview as an internal psychological factor supporting acceptance by children of socially significant values.

The influence of the social situation (pre-school educational institution/school) on development can be considered as an external factor influencing acceptance by children of socially significant values. Thus, the analyzed psychological and pedagogical literature and the performed empirical research allow us to state that worldviews is a guide for value adoption by children, which determined an individual's spiritual growth. Worldview value orientations, as a component of the system of spiritual values, are a basic formation in the structure of an individual's consciousness and self-consciousness that determines the further development of self-concept.

\section{Conclusion}

In conclusion we can say that formation of preschool and primary school children's worldviews is an important task. The experimental study of worldviews as a factor influencing value acceptance by children showed that happiness, family, friendship, and the beauty of the nature are the most important socially significant values for both preschoolers and primary schoolchildren. The following levels were distinguished in our research based on the manifested qualitative characteristics of worldviews: a formed picture of the world (the high level); expressed worldviews (the above average one); present worldviews (the average level); limited worldviews (the below average one); fragmentary worldviews (the low level). The analyzed emotion- al, cognitive, and behavioral manifestations of the worldview allowed us to generalize characteristics typical for children groups formed based on their levels of worldview formation. The data showed that the majority of Ukrainian pre-school and primary school children participated in this research had high or above-average levels of worldviews formation.

\section{Recommendations}

Our findings can be used by practical psychologists as well as by teachers in pre-school institutions and primary school as a basis in their activities. Girls' and boys' levels of worldview formation should be compared as a future research project, as well as a cross-cultural study. This research can serve as a basis for in-depth study of the spiritual sphere, a picture of the world and the influence of primary schoolchildren's value orientations on the regulation of their behavior.

\section{Limitations}

It is important to acknowledge that the present study is rich of data but comprehensive results and findings has certain limitations: geographical localization and sample. In future research, it is important to increase the number of participants.

\section{Conflicts of Interest}

The authors report that they do not have any conflicts of interest of affiliation, legal, financial, or commercial origin that could be related to the research.

\section{References :}

Appleton, J. E. (2020). A Mixed Methods Study Concerning Biblical Worldview Formation in Children and Adolescents through Informal Learning by Parents and/or Guardians. Doctoral Dissertations and Projects. 2731.https:// digitalcommons.liberty.edu/doctoral/2731

Barnett, W.S., \& Frede, E. (2010). The Promise of Preschool: Why We Need Early Education for All. Am. Education, 34, 21.

Davies, S., Janus, M., Duku, E., \& Gaskin, A. (2016). Using the Early Development Instrument to examine cognitive and noncognitive school readiness and elementary student achievement. Early Child. Res. Q., 35, 63-75.

Davranova, G. N. (2021). The use of interactive methods in forming the ecological worldview of preschool children. Middle European Scientific Bulletin, Volume 11, 334-341. ISSN 2694-9970 334

Demidov, A., Melnikov, T., Moskvina, A., \& Tretyakov, A. (2019). The organization of ecological education of pre-school children 
DOI (Issue): https://doi.org/10.31108/1.2021.7.5

employing media literacy education: Theory, national policy, scientometrics and vectors of development. Media Education, Vol. 54, No 4, 470-481. https://cyberleninka.ru/article/n/theorganization-of-ecological-education-of-per-school-children-by -means-of-media-literacy-education-theory-national-policyscientometrics/viewer

Hair, E., Halle, T., Terry-Humen, E., Lavelle, B., \& Calkins, J. (2006). Children's school readiness in the ECLS-K: Predictions to academic, health, and social outcomes in first grade. Early Child. Res. Q., 21, 431-454.

Helve, H. A. (2015). Longitudinal perspective on worldviews, values, and identities. Journal of Religious Education, volume 63, 95-115. https://doi.org/10.1007/s40839-016-0021-5

Johansson, I., \& Sandberg, A., (2010). Learning and participation: two interrelated key concepts in the preschool. European Early Childhood Education Research Journal, 18(2), 229-242 https:// doi.org/10.1080/13502931003784560

Karpenchuk, S. G. (2005). Theory and methods of education: textbook (2nd ed.). High school.

Katrenka, A. (2017). Specificity of world outlook and value orientations in the younger school-age: psychological and pedagogical aspect. Sophia, 2(2), 51-58 (in Russ.).

Korneeva, T. (2006). On the emotional attachment of the child to the mother. The child in kindergarten, 2, 82-87.

Leontiev, A. (1992). Mental development of the child in preschool age. Age and pedagogical psychology. Mosk. Univ., 42-50.

Peterson, C., \& Seligman, M. (2004). Character strengths and virtues: A handbook and classification. Washington, DC: American Psychological Association.

Piotrowska, P.J., Whitten, T., Tzoumakis, S., Laurens, K.R., Katz, I., Carr, V.J., Harris, F., \& Green, M.J. (2020). Transitions between socio-emotional and cognitive vulnerability profiles from early to middle childhood: A population study using multi-agency administrative records. Eur. Child Adolesc. Psychiatry, 29, $1659-1670$

Pirozhenko, T., Ladyvir, S., Karabaeva, I., \& Solovyova, L. (2017). The realities of the child's choice of socially significant values. Kyiv. URL http://lib.iitta.gov.ua/id/eprint/710011

Pirozhenko, T., Ladyvir, S., Solovyova, L., \& Karabaeva, I. (2016). Compass in the world of values of pre-schoolers. A textbook for older pre-school children. Kyiv. URL http://lib.iitta.gov.ua/id/ eprint/710149

Pirozhenko, T., Solovyova, L., Karabaeva, I., \& Khartman, O. (2020). Regulatory effect of value orientations in a child's life. Monograph. Kyiv. URL http://lib.iitta.gov.ua/id/eprint/722164

Pirozhenko, T., Solovyova, L., Ladyvir, S., \& Karabaeva, I. (2016). Value orientations of a child in the adult world. Training manual. Kyiv. URL http://lib.iitta.gov.ua/id/eprint/710118
Volume 7 Issue 5 (49) 2021

Pirozhenko, T., Ladyvir, S., \& Karasiova K. (2014). The child in the modern socio-space: a textbook. K.-Kirovograd. Imeks LTD., 3032. https://ib.iitta.gov.ua/8432/

Ray, K., \& Smith, M.C. (2010). The Kindergarten Child: What Teachers and Administrators Need to Know to Promote Academic Success in all Children. J. Fam. Econ. Issues, 38, 5-18.

Rokich, M. (1992). Methods of studying value orientations. The best psychological tests. Petrozavodsk. 120.

Ukhtomsky, A. (1996). The intuition of conscience. Petersburg writer.

UNICEF (2019). A World Ready to Learn Prioritizing Quality Early Childhood Education; United Nations Children's Fund: New York, NY, USA.

Vygotsky, L. (1991). Pedagogical psychology. M., 7-39.

Zdanevych, L., Syrova, Y., Kolosova, S., Pyvovarenko, M., \& Kurhannikova, O. (2020). Instilling the System of Values in Preschool Children in the Cultural and Educational Space. Universal Journal of Educational Research, 8(11B), 5991 - 5999. DOI: 10.13189/ujer.2020.082235

\section{Тамара Піроженко}

Член-кореспондент Національної академї педагогічних наук України, професор, доктор психологічних наук, завідувач лабораторії психологї дошкільника Інституту психологї̈ імені Г.С. Костюка Начіональної академії педагогічних наук України, м. Київ (Украӥна)

\section{Олена Хартман}

Кандидат психологічних наук, старший науковий співробітник лабораторії психології дошкільника Інституту психології імені Г.С. Костюка Національної академії педагогічних наук України, м. Київ (Україна)

\section{Ірина Сорока}

Кандидат психологічних наук, доцент, Джіндал Інститут Поведінкових Дисииплін, м. Соніпат (Індія)

\section{ОСОБЛИВОСТІ ПРОЦЕСУ ФОРМУВАННЯ ЦІН- НОСТЕЙ ТА РІВНІ СФОРМОВАНОСТІ СВІТО- ГЛЯДНИХ УЯВЛЕНЬ СЕРЕД ДІТЕЙ ДОШКІЛЬ- НОГО ТА МОЛОДШОГО ШКІЛЬНОГО ВІКУ}

\section{АНОТАЦІЯ}

Ціннісні орієнтації відображаються у світогляді дитини. Поширеною думкою вчених про початок формування світогляду людини є дитинство. Ключовою метою дослідження $є$ аналіз даних, отриманих в результаті проведення опитування дітей старшого дошкільного та молодшого шкільного віку за допомогою діагностичної бесіди «Фактори вибору дитиною соціально значущих цінностей», опис особливостей процесу фор(C) Tamara Pirozhenko, Olena Khartman, Iryna Soroka 


\section{DOI (Issue): https://doi.org/10.31108/1.2021.7.5}

мування цінностей та рівнів сформованості світоглядних уявлень серед дітей дошкільного та молодшого шкільного віку. Структурно-динамічні якісні характеристики феномену «ціннісних орієнтацій» представлені єдністю його компонентів:

1) когнітивного; 2) емоційного; 3 ) поведінкового.

Вибірку респондентів складали діти з різних регіонів України. Загальна кількість учасників - 306 дітей (166 дівчат, 140 хлопчиків): 190 старшого дошкільного віку - 6 років (44 - виховуються вдома, 146 відвідують дошкільні навчальні заклади); 116 молодшого шкільного віку - 7 років (що навчаються в початковій школі / 1 класі загальноосвітніх шкіл).

У дослідженні були виділені такі рівні, що базуються на якісних характеристиках проявів світоглядних позицій: сформована картина світу (високий рівень); виражені світоглядні уявлення (вище середнього); наявні світоглядні уявлення (середній рівень); обмежені світоглядні уявлення (нижче середнього); фрагментальні світоглядні уявлення (низький рівень). Високий рівень сформованості світогляду було визначено у $52,94 \%$ респондентів (162 дитини); вище середнього - у 20,91\% (64 дитини); середній - у 17,65\% (54 дитини); нижче середнього = у 8,5\% (26 дітей). Із загальної вибірки респондентів (306) не було виявлено жодного 3 низьким рівнем світогляду. Аналіз емоційних, когнітивних та поведінкових проявів світогляду дав змогу узагальнити типові характеристики груп дітей на основі формування картини світу.

Результати дослідження можуть бути використані практичними психологами, вчителями дошкільних та початкових класів та послужити основою для поглибленого вивчення формування духовної сфери, картини світу та впливу ціннісних орієнтацій учнів початкових класів на регуляцію їх поведінки.

Ключові слова: ціннісні орієнтації, світогляд, духовність, когнітивні, емоційні, поведінкові компоненти.

\section{Тамара Пироженко}

Член-корреспондент Национальной академии педагогических наук Украины, профессор, доктор психологических наук, заведующая лабораторией психологии дошкольника Института психологии имени Г.С. Костюка Национальной академии педагогических наук УкраиHbl, г. Киев (Украина)

\section{Елена Хартман}

Кандидат психологических наук, старший научный сотрудник лаборатории психологии дошкольника Института психологии имени Г.С. Костюка Национальной академии педагогических наук Украины, г. Киев (Украина)

\section{Ирина Сорока}

Кандидат психологических наук, доцент, Джиндал Институт Поведенческих Дисцииллин, г. Сонипат (Индия)

\section{ОСОБЕННОСТИ ПРОЦЕССА ФОРМИРОВАНИЯ ЦЕННОСТЕЙ И УРОВНЕЙ СФОРМИРОВАННО- СТИ МИРОВОЗЗРЕНЧЕСКИХ ПРЕДСТАВЛЕНИЙ СРЕДИ ДЕТЕЙ ДОШКОЛЬНОГО И МЛАДШЕГО ШКОЛЬНОГО ВОЗРАСТА}

\section{АННОТАЦИЯ}

Ценностные ориентации отражаются в мировоззрении ребенка. По мнению ученых детство является началом формирования мировоззрения человека. Ключевой целью исследования является анализ данных, полученных в результате проведения опроса детей старшего дошкольного и младшего школьного возраста с помощью диагностической беседы «Факторы выбора ребенком социально значимых ценностей», описание особенностей процесса формирования ценностей и уровней сформированности мировоззренческих представлений среди детей дошкольного и младшего школьного возраста. Структурно-динамические качественные характеристики феномена «ценностных ориентаций» представлены единством его компонентов:

1) когнитивного; 2) эмоционального; 3 ) поведенческого.

Выборку респондентов составили дети из разных регионов Украины. Общее количество участников - 306 детей (166 девочек, 140 мальчиков): 190 старшего дошкольного возраста - 6 лет (44 _воспитываются дома, 146 - посещают дошкольные учебные заведения); 116 младшего школьного возраста - 7 лет 
DOI (Issue): https://doi.org/10.31108/1.2021.7.5

(обучающихся в начальной школе / 1 классе общеобразовательных школ).

В исследовании были выделены следующие уровни, основанные на качественных характеристиках проявлений мировоззренческих позиций: сформированная картина мира (высокий уровень); выраженные мировоззренческие представления (выше среднего); имеющиеся мировоззренческие представления (средний уровень); ограниченные мировоззренческие представления (ниже среднего); фрагментальные мировоззренческие представления (низкий уровень). Высокий уровень сформированности мировоззрения был определен у 52,94\% респондентов (162 ребенка); выше среднего у 20,91\% (64 ребенка); средний - у 17,65\% (54 ребенка); ниже среднего - у 8,5\% (26 детей). Из общей выборки респондентов (306) не было выявлено ни одного с низким уровнем сформированности мировоззрения. Анализ эмоциональных, когнитивных и поведенческих проявлений мировоззрения позволил обобщить типичные характеристики групп детей на основе формирования картины мира.

Результаты исследования могут быть использованы практическими психологами, учителями дошкольных и начальных классов и послужить основой для углубленного изучения формирования духовной сферы, картины мира и влияния ценностных ориентаций учащихся начальных классов на регуляцию их поведения.

Ключевые слова: ценностные ориентации, мировоззрение, духовность, когнитивные, эмоциональные, поведенческие компоненты.

\section{How to cite (як цитувати):}

Pirozhenko,T. \& Khartman, O. \& Soroka, I. (2021). THE FEATURES OF PRE-SCHOOL AND PRIMARY SCHOOL CHILDREN'S VALUE FORMATION PROCESS AND THE DEVELOPMENT OF THEIR WORLD VIEWS. PSYCHOLOGICAL JOURNAL, 7 (5), 38-49. https:// doi.org/10.31108/1.2021.7.5.4 